\title{
Fiscal sustainability and dollarization: the case of Ecuador
}

\author{
María Lorena Marí Del Cristo a and Marta Gómez-Puig ${ }^{\mathrm{b}}{ }^{*}$ \\ Universitat de Barcelona
}

November 2015

Revised version

\begin{abstract}
This paper tries to disentangle the dynamic relationships between fiscal variables and economic activity in a small emerging economy characterized by full dollarization, namely, Ecuador. We find that fiscal policy in Ecuador seems to be sustainable, explained by its policy of debt payment through oil revenues, rather than by a fiscal discipline that dollarization is supposed to encourage. The non-oil tax revenues variable is a purely adjusting variable. This result suggests that in a dollarized country that cannot benefit from the "seignorage" revenues, the reliance on volatile oil revenues and on smoothing tax revenues leaves the economy's fiscal sustainability vulnerable.
\end{abstract}

JEL Classification: C32, E62, H60.

Keywords: Latin American countries; Ecuador; Fiscal policy sustainability; Dollarization; Debt; Cointegrated VAR.

\footnotetext{
* aDepartment of Economic Theory, Universitat de Barcelona, Av. Diagonal 696, 08034 Barcelona, Spain. E-mail: lmari@ub.edu. Tel: +34 934021 937. Fax: +34 934039 082. 'bDepartment of Economic Theory, Universitat de Barcelona and RFA-IREA, Av. Diagonal 696, 08034 Barcelona, Spain. Tel: + 34934020 113. Fax: +34 934039 082. E-mail:marta.gomezpuig@ub.edu. This work was supported by the by the Government of Spain under Grant number ECO2013-4836. Corresponding author: Marta Gómez-Puig (marta.gomezpuig@ub.edu)
} 


\section{Introduction}

Ecuador adopted the U.S. dollar as legal tender, replacing its own currency, the Sucre, in January 2000. ${ }^{1}$ The relative advantages and drawbacks of official dollarization to a country are well documented. ${ }^{2}$ To sum up, dollarization may lower the country's cost of foreign credit, may enhance the credibility of government fiscal policy and facilitate the control of inflation and interest rates. However, by adopting dollarization a developing country would accept at least three costly consequences: Its government would give up the revenue it enjoys from creating money ("seignorage" revenues) and its central bank would no longer serve as a lender of last resort to domestic banks or to control domestic monetary policy.

One of the arguments used by Ecuadorian's authorities to justify the decision to dollarize the economy was precisely that it may enhance fiscal discipline ${ }^{3}$ since this is one of the main benefits attributed by the literature to fixed exchange rate regimes ${ }^{4}$, which not only include a peg to a (hard) foreign currency -which may or may not be permanent-, but also: currency boards, currency unions, and dollarization. However, there is no consensus in the literature about this benefit. While some of authors (see, for

\footnotetext{
${ }^{1}$ In the early 1990s, Ecuador introduced various structural reforms that provided a certain degree of macroeconomic stability at least until the middle of that decade. However, a number of endogenous shocks - including, an inefficient fiscal policy and increasing financial dollarization - and exogenous shocks - including the impact of the climate oscillation, el Niño, and international oil prices - immersed the country in a period of economic stagnation that saw macroeconomic imbalances increase (Jacome, 2004). At the end of the twentieth century, Ecuador experienced one of the most serious crises in the history of the Republic with inflation rates being recorded at 30 percent per month. The government intervened in the banks and many public deposits were frozen. Internationally, Ecuador's standing was not good; it was in arrears with its private creditors and bondholders, while the International Monetary Fund, the World Bank and the Inter-American Development Bank withheld important loans that might have supported the Ecuadorian balance of payments. The country was in urgent need of radical measures that would stabilize expectations, avoid acute currency depreciation and hyperinflation, and restore economic and financial activity. At the same time, the government was in urgent need of radical measures that would allow it to escape being overthrown. At its head, President Mahuad faced the challenges of severe social and economic crisis - real GDP fell 7.3 percent, unemployment rose from 11 to 15 percent and an active indigenous movement called for political and economic reform. In an attempt to switch the focus from political issues to economic matters, he concluded that the radical solution was dollarization.

${ }^{2}$ See Alesina and Barro (2001), Berg and Borensztein (2000) and De Nicoló et al. (2005), and among other authors.

${ }^{3}$ See http://www.bce.fin.ec/documentos/PublicacionesNotas/Notas/Dolarizacion/dolarizar.html

${ }^{4}$ There is a very abundant literature examining the advantages and disadvantages of each exchange rate regime and its optimal choice [see, for example, Calvo and Reinhart (2002), Levy-Yeyati and Sturzenegger (2003), or Reinhart and Rogoff (2004), to name a few].
} 
example, Chang, 2000) point out that if a government is prone to lax fiscal behavior, dollarization may impose some discipline by making it more difficult for the government to finance excess fiscal behavior, as it would eliminate seigniorage revenues and inflationary finance and force the government to issue only foreign currency debt. Others, Tornell and Velasco $(1998,2000)$ among them, argue that dollarization differs from flexible exchange rates not in preventing lax fiscal behavior but in shifting its costs to the future. A government can always finance its expenditures today by borrowing. The cost of such a move would be a higher interest rate if exchange rates were flexible. Under dollarization, the interest cost may be lower but the fiscal expenditures have to be paid in some other way; in most cases, doing so means lowering expenditures, or looking for alternative resources: either increasing loans or raising taxes tomorrow. ${ }^{5}$ However, since, on the one hand, tax increases entail an immediate political cost, and, on the other, indebtedness is limited by both the intertemporal budget constraint and by external constraints imposed by financial institutions, the bottom line would be that by giving up control of its money supply, a full dollarization regime encourages fiscal discipline (enhancing policy credibility) but also constrains the country's fiscal room of maneuver's response in order to stabilize the economy in difficult times.

Therefore, the aim of this paper is to examine if dollarization has enhanced fiscal sustainability in a small open (emerging) economy characterized not only by full dollarization, but also by its substantial reliance on oil exports, namely, Ecuador. So, the interdependence and feedback between economic and fiscal variables will be analyzed in order to detect whether these variables present a different behavior than the one they had before dollarization.

\footnotetext{
${ }^{5}$ In addition, some empirical studies do not find evidence of fiscal discipline in countries with fixed exchange rate regimes [see Goldfajn and Olivares (2000) or Duttagupta and Tolosa (2006)], either.
} 
First, as Figure A in the Appendix I shows, Ecuadorian total debt-to-GDP ratio has fallen since $2000^{6}$. However, this trend has not been a consequence of a healthy and balanced fiscal system. Conversely, it must be understood in the light of the active management policy of its public debt in Ecuador which led to certain significant events in the country: (1) the default on its Brady bonds in the summer of 1999, (2) the debt reduction fiscal policy involving debt-buyback operations, and (3) the default on its external debt on December 2008. ${ }^{7}$ Second, Correa's government has been implementing a new expansive fiscal policy pattern (including programs addressed to reduce poverty or to rise education level) that has lead to fiscal deficits as can be observed in Figure B in the same Appendix I which shows that since 2007 the gap between government spending and tax revenues has increased. ${ }^{8}$ Summing up, the active management policy of its public debt implemented by Ecuadorian government by earmarking oil revenues to debt buybacks and by debt restructuring during the period 2000-2005 clearly explains the downtrend presented by the debt-to-GDP ratio from 2000. Indeed, from 2002 there was a macro-fiscal rule in Ecuador that limits its debt-to-GDP ratio to $40 \%$ which has resulted in a debt ratio of only 19\% in 2011 (see Ecuador Central Bank, 2013). However, since fiscal policy not only did not change (either by cutting government

\footnotetext{
${ }^{6}$ This is a very odd result in Latin American countries, that might be understood in the context of a very active management of their public debt by Ecuadorian authorities, since the literature on emerging economies has provided evidence of a lack of responsible credit policies of both governments and financial institutions in these countries, which has fostered important debt crisis in those countries (see Aggarwal (1996), Edwards $(1988,2008)$ and FDCI (1997) and among others).

${ }^{7}$ At the peak of a devastating economic crisis, Ecuador was forced to default on its Brady bonds ( $\$ 6.6$ bn of the total debt) in the summer of 1999. The restructuring process, officially implemented in August 2000, resulted in a reduction of close to 40 per cent in the face value of the tendered bonds. After this, Ecuador focused its fiscal policy on debt reduction. The 2002 Fiscal Responsibility, Stabilization and Transparency Act, created the Stabilization Fund for Social and Productive Investment and Debt Reduction (FEIREP), a special trust fund managed by the Central Bank. The FEIREP funds earmarked 70 per cent for debt-buyback operations; 20 per cent to stabilize oil revenues and for emergency spending, and 10 per cent for education and health spending. The Fund was replaced in 2005 by the Special Account for the Productive and Social Reactivation, Development of Science and Technology and the Fiscal Stabilization (CEREPS). The 70 per cent earmarking to debt reduction was reduced to 35 per cent. The debtto-GDP ratio fell from 86 per cent by end-2000 to about 34 per cent by end-2006. However, the government's targeted debt reduction policy caused the revalorization of its international bonds, making the debt buyback even more onerous and sparking President Correa's debt repudiation rhetoric. In December 2008 the debt-to-GDP ratio fell to around 23 per cent. The public external debt was at its lowest level for over three decades. Nevertheless, Ecuador decided to default again, emphasizing that it was "unwilling" rather than "unable" to pay".

${ }^{8}$ Ray and Kozameh (2012) and The World Bank (2004) offer more details about these fiscal expansive programs.
} 
expenses or by making an important effort to achieve a significant rise in taxes other than oil revenues), but Correa's government promoted a clearly expansive fiscal policy; the increase of Ecuadorian fiscal deficit since 2007, jointly with the reversal in the decreasing trend presented by the debt ratio from $2012^{9}$ and the fact that Ecuador, still relies on uncertain (they might vanish at some point in the future) and volatile oil revenues leave Ecuador vulnerable to future fiscal imbalances.

To our knowledge, no empirical study has yet explored the dynamic relationships between fiscal and macroeconomic variables in Ecuador in order to assess the effects of dollarization on its fiscal sustainability. This paper attempts to fill this gap and to contribute to this empirical literature by means of the application of a cointegrated VAR (CVAR) approach. So, with this goal in mind, the main objectives of this paper are, first, to determine the inter-linkages and feedback relationships that exist between fiscal and macroeconomic variables in Ecuador; second, to identify the main pushing and adjusting forces interacting in the long run equilibrium, i.e., permanent and transitory shocks; and third, to discuss the impulse responses of the variables included in the study to the already identified shocks.

The remainder of the article is organized as follows. Section 2 presents a literature review. Section 3 describes the theoretical approach. Section 4 presents the econometric methodology and the data used in the empirical analysis. Section 5 explains the results. Finally, section 6 summarizes the main concluding remarks.

\footnotetext{
${ }^{9}$ Currently, in the aftermath of the world financial and economic crisis that followed Lehman Brothers collapse in 2008, Ecuador has already reversed (from 2012) the abovementioned downward trend.
} 


\section{Literature review}

As far as we know, few studies have examined the effects of dollarization on fiscal policy. ${ }^{10}$ Concretely, in the case of Ecuador, only a handful of authors have examined its fiscal policy during the dollarization period. Cueva (2008) and Almeida et al. (2006) report that the legal framework for the distribution and earmarking of oil and tax revenues is cumbersome and creates large rigidities in fiscal management; Barnhill and Kopits (2003), in developing a Value-At-Risk approach, find that the volatility of sovereign spreads and of oil prices constitutes a major source of risk for Ecuador's public sector; Alvarado et al. (2004), calculate debt threshold sensitivities for different assumptions regarding revenue volatility and expenditure adjustments; Mejía et al. (2006) claim that dollarization has limited the range of fiscal instruments available to governments and warn of the dangers of dependency on oil revenues, which they define as a source of instability in a balanced budget; finally, The World Bank and the InterAmerican Development Bank (2004) expose that, although Ecuador's fiscal stance has improved substantially when compared to the sudden stop crisis it experienced in 199899, the country is still quite vulnerable to external shocks due to the volatility of government's revenues and high inflexibility of government non-interest expenditure. ${ }^{11}$

However, as stated before, as far as we know, no empirical study has yet explored the dynamic relationships between fiscal and macroeconomic variables in Ecuador in order to assess the effects of dollarization on its fiscal sustainability by means of a CVAR approach, which is best-suited for testing our hypothesis ${ }^{12}$ and may shed some light on

\footnotetext{
${ }^{10}$ Literature is not so scarce on the effects of fiscal policy in other forms of extreme rate regimes such as a Currency Boards, though. See, for instance, Grandes and Reisen (2003) in the case of Argentina, and Vladimirov and Neycheva (2009) in the case of Bulgaria.

${ }^{11}$ The World Bank (2004) also emphasize that dollarization has left fiscal policy as the unique device to counteract shocks, and propose a reduction in expenditure entitlements and the consolidation of a reliable oil stabilization fund in order to achieve more flexibility in fiscal policy.

${ }^{12}$ The advantages of this methodology over others to analyse the inter-linkages and feedback effects among variables are clearly presented in Hoover et al. (2007) and Juselius (2009).
} 
how best to harmonize fiscal policies in countries with extreme exchange rate regimes such as monetary unions or dollarized countries (recall that a dollarization can be defined as a unilateral monetary union). Indeed, this methodology has been broadly used by other authors to analyze these dynamic relationships in other economies, but mainly developed ones.

In this sense, Favero et al. (2011) highlight the importance of including feedback between fiscal and macroeconomic variables in VAR models, since it conditions the reactions of both variables to fiscal shocks. Bohn (1998) proposes error-correction-type policy reactions as a promising alternative for understanding debt and deficit problems in the United States. Other empirical studies include Bohn (2007) for the US; Collignon (2012) for Europe; and Fincke and Greiner (2012) for selected countries in the euro area. The analysis of fiscal sustainability in developing countries by means of a VAR approach is much scarcer though. Some exceptions are Kia (2008) and El Anshasy and Bradley (2012) who undertake the analysis for oil-exporting countries and emphasize the procyclicality of fiscal policy in these countries; ${ }^{13}$ and Martins (2010), who develops a CVAR to assess the dynamic relationships between foreign aid inflows, public expenditure, revenues and debt in Ethiopia. ${ }^{14}$

\section{Theoretical approach.}

A fiscal shock (a shift in taxes or in government spending) at some point in time puts a constraint on the path of taxes and spending in the future, since the government intertemporal budget constraint (IBC) will eventually have to be met. This is the reason why some studies of the effects of fiscal policy based on VAR models have been

\footnotetext{
${ }^{13}$ El Anshasy and Bradley (2012) find that, in the long run, the higher the oil prices, the larger government spending, while in the short run government expenditure rises less than proportionately to the increase of oil revenues.

${ }^{14}$ Actually, an analogy between oil revenues and aid inflows can be made, since both variables are affected by external shocks; the former depends on price volatility, and the latter on donors' goodwill.
} 
extended to satisfy the IBC [see Konstantinou (2004), Bohn (2005) or Favero and Giavazzi (2007), to name a few] and why the CVAR approach developed in this paper will also be inspired by the theoretical predictions of the IBC theory.

\subsection{The Model}

In this section, we set out a simple budget relationship along with the restrictions that must be satisfied for sustainability. Consider that an increasing debt-to-GDP ratio depends on the economic environment $\left(r_{t}-g_{t}\right) d_{t-1}$, and on the primary surplus. If the interest rate $\left(r_{t}\right)$ exceeds the growth rate $\left(g_{t}\right)$, then the debt-to-GDP ratio $\left(d_{t}\right)$ will increase indefinitely unless there is a primary surplus which can offset the rising debt service. The paths of public debt implied by the sequences of primary surplus $\left(s_{t}\right)$ and economic environment $\left(r_{t}-g_{t}\right)$ are:

$$
d_{t+n}=\left(\prod_{k=0}^{n}\left[1+(r-g)_{t+k}\right] d_{t-1}-\sum_{j=0}^{n}\left(\prod_{k=j+1}^{n}\left[1+(r-g)_{t+k}\right]\right) s_{t+j}\right.
$$

Assuming the economic environment as given and constant, the accumulation of debt over several periods $\mathrm{t}=1 \ldots \mathrm{n}$, will be:

$d_{t+n}=(1+r-g)^{n} d_{t}-\sum_{j=0}^{n}(1+r-g)^{n-j} S_{t+j}$

If we divide by $(1+r-g)^{n}$ and arrange terms, we obtain:

$\frac{1}{(1+r-g)^{t+n}} d_{t+n}=d_{t}-\sum_{j=1}^{n} \frac{S_{t+j}}{(1+r-g)^{j}}$ 
Assuming that the transversality condition holds, ${ }^{15}$ fiscal policy will satisfy the intertemporal budget constraint (IBC) because it is on a path in which the present value of expected future primary surpluses equals the initial debt:

$$
d_{t}=E\left(\sum_{j=0}^{\infty} \frac{S_{t+j}}{(1+r-g)^{j}}\right)
$$

Equation (4) states that debt sustainability requires a variation in the primary budget surplus. A surplus is needed when the growth rate falls below the rate of return on government bonds. Thus, whether fiscal policy is sustainable or not depends on the sign of the fiscal policy reaction with respect to the target: i.e., if an increase in debt is followed by an increase in primary surpluses, debt is sustainable. In the long run, the debt-to-GDP ratio is required to converge on an equilibrium position that is determined by the nominal growth rate, target reference values, and adjustment coefficients. ${ }^{16}$

In order to explain the sustainability of oil-producing countries, Kia (2008) extends Barro's $(1979,1986)$ tax smoothing model by introducing energy revenues. In Barro's approach, the base of real taxable income is a deterministic variable $\left(y_{t}\right)$, a fixed fraction of real GDP that generally depends on the path of tax rates. Kia (2008) assumes GDP to be a function of the country's energy income.

Let $\tau$ be the average tax rate and $\tau y_{\mathrm{t}}$ the real tax revenues. The total government revenues of an oil-producing country are, therefore, the sum of $\tau y_{\mathrm{t}}$ and $E N_{t}$, the oil revenues derived from the exports of the natural resource. The government budget

\footnotetext{
15 The initial debt equals the expected present value of future primary surpluses, if and only if discounted future debt converges to zero (Bohn, 2005).

${ }^{16}$ Collignon (2012) adopting the fiscal reaction function for European countries $\Delta s_{t}=\alpha\left(d e f_{t}-z_{1}\right)+\beta\left(d e b t_{t}{ }^{-} z_{2}\right)$ relates the deficit and debt ratios with the primary surplus. $Z_{1}$ and $Z_{2}$ are the target reference values for the deficit and debt ratios respectively under the Stability and Growth Pact; $\alpha$ and $\beta$ are the adjustment speed coefficients by which governments respond to the deviation from the deficit and debt ratio respectively.
} 
constraint, Equation (4), with constant real interest rate, $r$, and in a situation in which the country has energy income will then be:

$d_{t}=E\left(\sum_{j=0}^{\infty} \frac{\left(\tau y_{t+j}+E N_{t+j}\right)-\left(G o v_{t+j}\right)}{(1+r-g)^{j}}\right)$

where the primary surplus $S_{t+j}$ from Equation (4) now includes energy revenues $E N_{t .}{ }^{17}$ If both primary balance and debt are non-stationary, according to equation (5) the two variables should cointegrate and debt would be sustainable. ${ }^{18}$

In line with Kia (2008), we have to make several assumptions for our empirical purposes, which are to set long run relations between the variables. First, we assume that both the real government expenditure, Gov , and the real tax base, $y_{t}$, are expected to fluctuate around the current rate of the growth of the economy $g^{19}$. Second, the expected present value of energy income is also its current value. This means that all economic agents expect energy revenues not to change over the remaining life of the oil reserves. ${ }^{20}$ Third, the oil reserves are expected to last forever ${ }^{21}$ which implies a long run relationship between oil revenues and fiscal variables, ${ }^{22}$ or the Ecuadorian government

\footnotetext{
${ }^{17}$ Alvarado (2004) points out that increasing resource exploitation to pay the debt does not affect sustainability since it is assumed that oil reserves have the same return as the government's other financial assets and liabilities.

18 This concept of debt sustainability is presented by Hamilton and Flavin (1986) and Trehan and Walsh (1991). However, Bohn (1998) shows the existence of cointegration between debt, primary balance and other variables non debt determinants of the primary surplus, such as the level of temporary government spending (GVAR) and a business cycle indicator (YVAR).

${ }^{19}$ Aggregate real income $(\mathrm{Y})$ grows at the constant rate $\rho$ and government expenditure $(\mathrm{G})$ at the constant rate $\Upsilon$. Clearly, $\rho=\Upsilon$ is the only specification within the constant growth rate setup that allows for a positive and finite steady state value of G/Y, (see Barro, 1979).

${ }^{20}$ This means that all economic agents expect energy revenues not to change over the remaining life of the oil

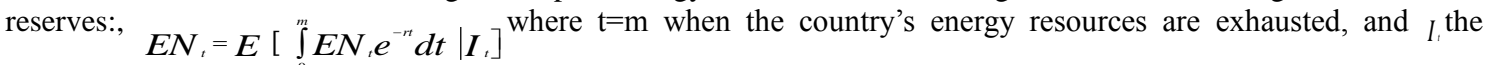
information available at time $\mathrm{t}$, including the state of the economy (see Kia, 2008).

${ }^{21}$ This assumption, however, is unsustainable based on OPEP's Annual Statistical Bulletin which states that Ecuador has about 8.24 bn barrels of proven reserves and an exportable trend of 334 thousand barrels per day in 2011, that is, seventy per cent of its production.

${ }^{22}$ In growth models with optimizing households, others authors (see Ramsey (1928) among them) use a similar kind of assumption when considering that the representative, infinite-lived household seeks to maximize their overall utility.
} 
should have to diversify tax revenues and/or cut government expenditure when oil resources were exhausted (see Kia, 2008).

\section{Econometric Methodology and Data}

\subsection{Econometric Methodology}

The study of the effects of fiscal policy on macroeconomic variables is usually carried out by estimating a vector autoregressive (VAR) model of the form:

$$
X_{t}=\sum_{i=1}^{k} \prod_{i} X_{t-i}+e_{t}
$$

Where $X_{t}$ includes the minimum set of variables required for the VAR analysis, i.e., government spending net of interest, net tax revenues, output, inflation and interest rate (see Perotti, 2002). In our analysis, this set of variables will be extended in order to include the debt level since the importance of monitoring debt dynamics when analysing fiscal policy has been stressed by many authors [see (1998), Favero and Giavazzi (2007) and Romer and Romer (2010) among them]. ${ }^{23}$

Following Engle and Granger (1987), Johansen and Juselius (1990, 1992) extend the VAR model by applying the concepts of cointegration and error correction to analyse long run relations among non-stationary variables. This extension is referred to as the Cointegrated VAR (CVAR) with the following representation:

$$
\Delta x_{t}=\Gamma_{1} \Delta x_{t-1}+\alpha \beta^{\prime} x_{t-1}+e_{t}
$$

\footnotetext{
${ }^{23}$ Bohn (1998) shows that the feedback obtained from the debt to tax and government spending ratios is statistically significant and economically relevant; Romer and Romer (2010) claim that the effect of a US tax shock on output depends on whether the change in taxes is motivated by the government's desire to stabilize the debt or not; and Favero and Gavazzi (2007) also find that interest rates depend on future monetary policy and the risk premium, both variables being affected by the debt dynamics. Hence, the absence of an effect of fiscal shocks on the long-term interest rates, a frequent outcome in VAR-based research that omits debt level, may be due to a misspecification.
} 
The moving average representation of the CVAR is given by:

$x_{t}=C \sum_{i=1}^{t} e_{i}+C^{*}(L) e_{t}+x_{0}$

where $\quad C=\beta_{\perp}\left(\alpha_{\perp}^{\prime} \Gamma \beta_{\perp}\right)^{-1} \alpha_{\perp}^{\prime} \quad$ or $\quad C=\beta_{\perp}^{*} \alpha_{\perp}^{\prime}$

Thus, in the autoregressive representation $\beta$ determines the common long run relations (r) and the $\alpha$ their loadings, whereas in the moving average representation $\alpha_{\perp}^{\prime}$ determines the common stochastic trends (p-r) or pushing forces of the system, and $\beta_{\perp}^{*}$ their loadings. A zero row in $\alpha$ corresponds to a unit vector in $\alpha_{\perp}^{\prime}$.

By premultiplying (7) with a non-singular $p x p$ matrix B we obtain the CVAR model with simultaneous effects:

$B \Delta x_{t}=B_{1} \Delta x_{t-1}+B \alpha \beta^{\prime} x_{t-1}+u_{t}$

where $\quad u_{t}=B e_{t}$

We can rewrite (8) using $e_{t}=B^{-1} u_{t}$ :

$x_{t}=C^{\sim} \sum_{i=1}^{t} u_{i}+C^{*}(L) B^{-1} u_{t}+x_{0}$

where $\mathrm{C}^{\sim}=C B^{-1}$.

Making a distinction between $r$ transitory and p-r permanent shocks it is assumed that all structural shocks are linearly independent, $E\left(u_{t} u_{t}^{\prime}\right)=I_{p}$, where $u_{t}=\left[u_{s}, u_{l}\right]$, comprises the shocks with short and long run effects respectively. Defining these shocks by (11) its added $p \times p$ additional parameters to the unrestricted CVAR so we need to 
impose the same number of restrictions on the parameters of the model to achieve just identification.

The methodology is extensively described in Juselius (2006). She shows how the VAR model, allowing for unit roots and, hence, cointegration, specifies economically meaningful short and long-run structures, such as steady-state relationships and common trends, interactions, and feedback effects. In our empirical analysis, equation (5) could be rewritten as:

$d_{t}-E\left(\sum_{j=0}^{\infty} \frac{\left(\tau y_{t+j}+E N_{t+j}\right)-\left(G o v_{t+j}\right)}{(1+r-g)^{j}}\right)=v_{t}$

where the deviation from the steady-state value, $v_{t}$, measures the extent of excess expected surplus (positive or negative) in the economy at time t relative to its long run value. We need $v_{t}$ to be a stationary process, implying that the economic forces should be activated when $v_{t} \neq 0$, pulling the process back towards its long run benchmark value. This approach capture the rich dynamics of fiscal aggregates through the identification of two sorts of fiscal policy shocks; on the one hand, shocks allowing variables to adjust to the long run relationship; on the other, shocks which are pushing the process away from equilibrium. ${ }^{24}$

\subsection{Data}

We use monthly data obtained from the Central Bank of Ecuador covering the period 2001:01 to $2013: 03 .^{25}$ The fiscal variables are the log of government spending net of

\footnotetext{
${ }^{24}$ Perotti (2002) describes the four approaches to identify fiscal shocks that have been used in the literature: (1) The "narrative approach"; (2) the Cholesky ordering; (3) the sign restrictions on the impulse responses rather than the linear restrictions on the contemporaneous relations between reduced form innovations and structural shocks, and finally (4) the structural VARs.

${ }^{25}$ We exclude data corresponding to the first year after dollarization since the different economic variables were still adjusting to the new exchange rate regime. Detailed charts regarding the evolution of the variables for the predollarization versus the post-dollarization period can be found in "Estadísticas Macroeconómicas. Presentación estructural". Ecuador Central Bank (2013).
} 
interests, $L G O V_{t}$, and also including interests, $L T G O V_{t}$; the $\log$ of non-oil tax revenues, $L R E V_{t}$, and the $\log$ of oil revenues, $L O R E V_{t}{ }^{26}$ The remaining variables are the log of Economic Activity Index (EAI) represented by $L E A I_{t}$; the $\log$ of the total (external and internal) debt-to-GDP ratio, $L D E B T_{-} G D P_{t}$, and the inflation rate, $L I N F_{t}$. These variables are not seasonally adjusted, since such an adjustment could modify the relations between the variables. ${ }^{27}$

The $E A I_{t}^{28}$ variable was chosen as a proxy of the economic activity evolution instead of the GDP because Ecuador was dollarized in 2000:1 and the GDP is only reported annually or quarterly, whilst the $E A I_{t}$ variable is generated on a monthly frequency. Therefore, given that the correlation between the two variables is very high, in order to have availability of the highest number of observations from the dollarized period we made the decision to use the $E A I_{t}$ variable. In order to have a complete characterization of the dynamic relationships we want to examine, a proxy for the price pressures should be included. We decided to include the inflation rate in the model, although since 2000 an important inflation reduction took place in Ecuador, not only two digit inflation rates (that were usual from 1990 to 2001) disappeared, but also during the period 2004-2012 it remained very stable around the 4\% level, with the only exception of 2008-2009 following the increase in oil prices ${ }^{29}$ (see Figure C in the Appendix I).$^{30}$

\footnotetext{
${ }^{26}$ The oil sector accounts for about 50 per cent of Ecuador's export earnings and about one-third of all tax revenues (US Energy Information Administration Report 2012). Besides, the inclusion of the oil revenues as an endogenous variable prevents using other variables such as international oil prices, since its high correlation would have entailed multicolinearity problems.

${ }^{27}$ See Lütkepohl (2004).

${ }^{28}$ The Economic Activity Index, which is calculated on a monthly frequency, involves production variables that show the trend of the economic activity. It is calculated as a quantum production indicator and has the mathematic form of Laspeyres index. It takes into account industries that cover more than 60 percent of GDP such as banana, coffee, cacao, fishing, oil refiner, manufacture, electricity, construction, transport or financial services. See: http://www.bce.fin.ec/index.php/component/k2/item/313-indice-de-actividad-econ\%C3\%B3mica-coyuntural-ideac for more details on its calculation.

${ }^{29}$ Marí del Cristo and Gómez-Puig (2013) by means of a VECM analysis suggest that rising rates of imports from trade partners other than the United States and subsequent real effective exchange rate depreciations are causing the pass-through to move away from zero in Ecuador since it is importing inflation from its main trading partners (most of them emerging countries with appreciated currencies).

${ }^{30}$ The CVAR framework does not require all series to be $\mathrm{I}(1)$. All that is required is that they are at most $\mathrm{I}(1)$. An $\mathrm{I}(0)$
} 
The rest of variables included in our analysis are plotted in Figure D in the Appendix I; whilst Table A in the same Appendix presents a brief description of the six endogenous variables we finally used in the CVAR model. Hence, the vector of endogenous variables comprised in the CVAR model is the following:

$X_{t}=\left[L R E V_{t}, L O R E V_{t}, L G O V_{t}, L E A I_{t}, L I N F_{t}, L D E B T_{-} G D P_{t}\right]^{31}$

\section{Empirical Results}

To analyze whether the long run relation described in equation (7) exists (i.e. whether the fiscal policy of Ecuador is on a sustainable path), and to establish which different shocks may have permanent and transitory effects on the variables, we shall focus on the success of a well-specified empirical model. Once the assumptions upon which our statistical model is based are satisfied, we impose restrictions in order to discover interactions of the variables. This method, described as general-to-specific, is best explained in Hendry (1995).

Since statistical inference from the VAR model is only valid provided the parameters are constant and the residuals do not present autocorrelation or skewness, ${ }^{32}$ we choose four lags $(\mathrm{k}=2)$ to solve the problem of autocorrelated residuals and include three dummies to eliminate the problem of skewness due to data outliers. ${ }^{33}$ The first outlier is

variable in a CVAR model means a cointegrating vector on its own. Using the trace test, we reject non-stationarity for Ecuadorian inflation (which is expected due to the fact that its value is close to zero throughout all the sample period), but we do not reject it for the rest of variables included in our models.

${ }^{31}$ These variables are not cyclically adjusted since fiscal variables have been collected on a monthly frequency basis, while GDP is only quarterly or annually reported by the Central Bank of Ecuador. If the intention was to isolate the cyclical effect from fiscal variables, we would had to create monthly GDP by interpolation techniques, with the risk of underestimating or overestimating the business cycle effect. Neither creating quarterly or annually fiscal variables to adjust them is a suitable option because, first, we need the maximum of observations to ensure enough degrees of freedom to carry on diverse hypothesis on the CVAR, and second, we would lose valuable information intrinsic in monthly frequency.

32 Simulation studies have shown that valid statistical inference is sensitive to the violation of some of the assumptions, including parameter non-constancy, autocorrelated residuals and skewed residuals, while quite robust to others, such as excess kurtosis and residual heteroscedasticity [see Rahbek et al. (2003) and Cheung and Lai (1993)]

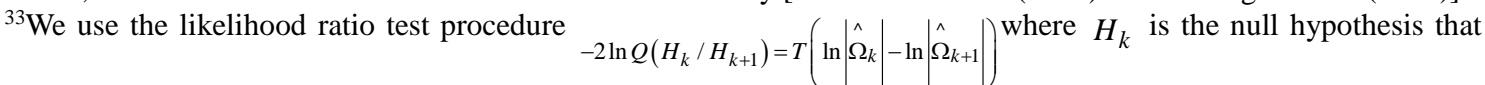

the model needs $\mathrm{k}$ lags and $H_{k+1}$ is the alternative hypothesis that the VAR needs $\mathrm{k}+1$ lags. This test is distributed as 
associated with the moment when Ecuador restructured its external debt in June 2009. ${ }^{34}$

The second outlier corresponds to an increase in the active interest rate in October 2001 despite dollarization ${ }^{35}$ and influenced Ecuadorian budget revenues in February 2008. Therefore, we introduce two permanent dummies, dum0906 $6_{\mathrm{t}}$ and $d u m 0802_{\mathrm{t}}$ whose value is 1 if $t$ refers to that date and zero otherwise. We also include a transitory dummy $\left(\right.$ dum $0609 \mathrm{t}_{\mathrm{t}}$ ) which has the value 1 if $t=2006: 09,-1$ if $t=2006: 10$, and zero otherwise, in order to eliminate the third outlier corresponding to the $L O R E V_{t}$ residuals. ${ }^{36}$ All our statistical tests are now acceptable. The univariate normality tests only reject normality on the residuals of $L D E B T_{-} G D P_{t}$ and $L I N F_{t}$ because of the presence of some kurtosis, but they show little skewness. ${ }^{37}$ Thus, our model should be well-specified and the empirical results might be reliable.

Therefore, we calculate the trace test statistics (Johansen, 1996), one including both seasonal and permanent dummies, and a second without dummies as a sensitivity analysis.

\section{[Insert Table 1 here]}

Table 1 in Appendix II shows that both tests determine the existence of two cointegrating relations. Thus, the IBC is fulfilled in Ecuador, since the variables involved in equation (7) cointegrate, which was expected, as Figure A depicts a

$\chi^{2}$ with $\mathrm{p}^{2}$ degrees of freedom. However, we also observe the Akaike, the Schwartz and the Hannan-Quinn information criteria to finally decide the optimal number of lags, as well as the Lagrange Multiplier test to check for left-over residual autocorrelation in each $\operatorname{VAR}(\mathrm{k})$.

34 The total external debt ratio was reduced from 106 per cent GDP at the end of 1999 to around 98 per cent in 2000 (see Quispe-Agnoli, 2006). In June 2009 the Correa government defaulted on $\$ 3.2$ billion of foreign public debt, and then completed a buyback of 91 per cent of the defaulted bonds (see Sandoval and Weisbrot, 2009).

${ }^{35}$ After dollarization, in spite of the elimination of money creation, during 2000 and 2001 both inflation and active interest rates still remained above international levels (see Larrea, 2004), just after these years Ecuador experienced a reduction in interest rates as Figure D in the Apendix I shows.

36 Two contributing factors to the positive fiscal performance occurred in 2006. First, in April 2006 Congress approved a reform to the Hydrocarbons Act stipulating that when crude prices exceed the level agreed in the contract with each private company, the State will be entitled to 50\% of the revenues from those oil exports. Second, in May 2006 the Minister for Energy and mines announced the termination of the contract between State and Occidental Petroleum with important oilfields (Block 15 of the Amazon region and the unified fields of Eden Yuturi and Limoncocha) now being managed by the state-owned enterprise PETROECUADOR (see ECLAC, 2006).

${ }^{37}$ Our non-normal residuals (from $A I R_{t}, L D E B T_{-} G D P_{t}$ ) present positive and negative skewness less than 0.14, which is inside the range suggesting a normal population (see Doane and Seward, 2011). 
downward trend for the debt-to-GDP ratio. Once the CVAR model is restricted to rank=2 and has passed a number of diagnostic tests for parameter constancy, we begin to impose restrictions on $\beta$ and $\alpha$. These are tested with a likelihood ratio test procedure described in Johansen (1996), Johansen and Juselius (1990) and Juselius (2006).

We test three types of restrictions on $\beta$ vectors: long-run exclusion of a specific variable, stationarity of individual variables, and stationarity of linear combinations of variables. These tests allow the identification of the long-run structure of the $r$ stationarity cointegrating relations. ${ }^{38}$ As Table 2 in Appendix II illustrates, one variable can be excluded from long run relations, namely the total debt $L D E B T_{-} G D P_{t .}{ }^{39}$

\section{[Insert Table 2 here]}

The exclusion of the debt variable from the model might be related to the fact that, as it has been mentioned; Ecuadorian authorities have been managing quite actively its stock of public debt, by earmarking oil revenues to debt buybacks and by debt restructuring.

So, our new model is:

$X_{t}=\left[L R E V_{t}, L O R E V_{t}, L G O V_{t}, E A I_{t}, L_{I N F}\right]^{40}$

We repeat all the tests described above for this new model and their results are presented in Tables 3 and 4 in Appendix II.

[Insert Tables 3 and 4 here]

Following Martins (2010), several hypotheses can be tested on the cointegrating vectors. Table 5 in Appendix II shows some of them. On the one hand, whether Ecuador

\footnotetext{
${ }^{38}$ In order to identify the long run structure we need to impose at least $\mathrm{r}(\mathrm{r}-1)$ restrictions on $\beta$ vectors.

${ }^{39}$ This is to be expected since the total debt-to-GDP ratio is unrelated to the path of its fiscal surpluses but to the 1999's default.

40 The model's specification has changed to require only three lags and the transitory dummy dum0609t. The inclusion of interests in government expenditure $\left(L T G O V_{t}\right)$ does not change the main results.
} 
depends on oil revenues to ensure a balanced budget or whether tax revenues are not sufficient to achieve a balanced budget can be tested by hypotheses $H_{1}$ and $H_{2}$, respectively. On the other, the "Additionality" hypothesis $\left(H_{3}\right)$ which implies that oil revenues produce equivalent government expenditure can also be tested. The coefficient corresponding to oil revenues can offer relevant information: (i) if is higher than 1 it may suggest that public expenditure increase more than the amount of the net oil revenues; (ii) if is close to one it implies oil revenues generate an equivalent increase in government expenditure; (iii) if is lower than 1 it is a sign of fungibility, this term describes situations where earmarked oil revenues are indirectly used for unintended purposes. Finally, “Tax Displacement” hypothesis $\left(H_{4}\right)$ relates higher oil revenues to the government's disincentive to increase taxes, corresponding with a coefficient of oil revenues lower than $1^{41}$.

\section{[Insert Table 5 here]}

The results displayed in Table 5 in Appendix II suggests that oil revenues are financing fiscal deficit $\left(H_{l}\right)$, and that there exists a positive relationship between oil revenues and government expenditure $\left(H_{3}\right)$ and a negative relationship between oil and tax revenues $\left(H_{4}\right)$. Table 7 in Appendix II illustrates the final estimations which state the "Additionality" of oil revenues to government expenditure and tax displacement.

In order to assess the long run behavior of the variables we test a zero row and a unit vector in $\alpha$. Concretely, testing a zero row in $\alpha$ is equivalent to examine whether a variable is weak exogenous for the long run relationship which defines common driving trends (the pulling and pushing forces) in the system, since these variables do not adjust to the long run relationships. They (through their own shocks) can affect, but not be affected by, the rest of variables. In contrast, testing a unit vector in $\alpha$ reveals which

\footnotetext{
${ }^{41}$ These two hypotheses have been used in a previous study in Martins (2010)
} 
variable is purely adjusting to the long run relationships, i.e., its own shocks have only transitory effects on the remaining variables in the system. The results from this analysis are presented in Table 6 in Appendix II.

\section{[Insert Table 6 here]}

From Table 6 we can conclude that only two variables are purely adjusting: $L R E V_{t}$ and $L O R E V_{T}$ variables; while $L G O V_{t}, E A I_{t}$ and $L I N F_{t}$ variables seem to be the pushing forces of the system.

Moreover, when identifying our $\prod_{i}=\alpha \beta^{\prime}$ matrix, using the structure that imposes $H_{3}$ (since it gave the highest p-value in the analysis shown in Table 5), beta vectors describe two long run relationships which are presented in Table $7^{42}$.

\section{[Insert Table 7 here]}

The first suggests a linkage between oil revenues and government expenditure variables, while the second reveals the relationship that exists between traditional deficit (government spending minus tax revenues) and economic activity. The structure illustrated in Table 7 complements the results presented in Table 6 because it shows to which long run relationship the two variables $L R E V_{t}$ and $L O R E V_{t}$ are purely adjusting. Tax revenues are adjusting to the second long run relationship; and oil revenues adjust to government demands. Note the borderline significance (based on the Student's $t$ statistic) of the adjustment coefficient corresponding to $L G O V_{t}$; this is because this variable generates both transitory and permanent shocks. We will see this afterwards when we analyze the structural moving average representation of the cointegrated VAR.

\footnotetext{
${ }^{42}$ We also include the estimations of imposing $\mathrm{H}_{1}$ and $\mathrm{H}_{4}$ in Table 7. Both hypotheses have been used in Section 5.1. to examine the robustness of results.
} 
The impulse response functions are calculated with the following structurally identified MA model: ${ }^{43}$

$$
\left(\begin{array}{l}
\operatorname{LREV}_{t} \\
\operatorname{LOREV}_{t} \\
\operatorname{LGOV}_{t} \\
\operatorname{LEAI}_{t} \\
\operatorname{LINF}_{t}
\end{array}\right)=\left(\begin{array}{l}
\sum_{i=t}^{t} u_{s 1, i} \\
\mathrm{OO} * * * * * \\
\mathrm{OO} * \mathrm{OO} \\
\mathrm{OO} * * 0 \\
\mathrm{OO} * * *
\end{array}\right)\left(\begin{array}{l}
t \\
\sum_{i=t}^{t} u_{s 2, i} \\
\sum_{i=t}^{t} u_{l 1, i} \\
\sum_{i=t}^{t} u_{l 2, i} \\
\sum_{i=t}^{t} u_{l 3, i}
\end{array}\right)+\left(\begin{array}{l}
* 0 * * * \\
* * * * * \\
* * * * * \\
* * * * * \\
* * * * *
\end{array}\right)\left(\begin{array}{l}
u_{s 1, t} \\
u_{s 2, t} \\
u_{l 1, t} \\
u_{l 2, t} \\
u_{l 3, t}
\end{array}\right)+C_{1} B^{-1}\left(\begin{array}{l}
u_{s 1, t-1} \\
u_{s 2, t-1} \\
u_{l 1, t-1} \\
u_{l 2, t-1} \\
u_{l 3, t-1}
\end{array}\right)
$$

The exclusion restrictions on the permanent shocks are defined by assuming: firstly, government spending inertia, and secondly, that a nominal shock cannot have a long run effect on real income. The other exclusion restriction on the transitory shocks is defined by assuming "sticky" taxes, so tax revenues do not react immediately to the second transitory shock. Therefore, we estimate the $B$ matrix normalized at the largest coefficient in each row.

\section{[Insert Table 8 here]}

The results, presented in Table 8 , define how the orthogonalized permanent and transitory shocks are associated with the estimated CVAR residuals. Recovering the last

\footnotetext{
${ }^{43}$ Since we have five variables, the $B$ matrix adds 25 new coefficients. The assumption that $\mathrm{u} \sim \mathrm{IN}(0, \mathrm{I})$ implies $((\mathrm{p} *(\mathrm{p}+1) / 2)=15)$ fithteen restrictions on $B$ (five unit coefficients on the diagonal elements and ten zero restrictions on the off-diagonal elements). Six additional restrictions $((p-r) * r=6)$ are necessary to separate transitory from permanent shocks, and four more restrictions are required to achieve a just-identified structural MA model. These four extra restrictions are essential because there are two possible sequences of the transitory shocks and two possible sequences of the permanent shocks. A single specification can be obtained by imposing three exclusion restrictions on the common trends and one exclusion restriction on the transitory impulse responses.
} 
two rows and substituting in the equation: $u_{t}=B e_{t}$, we obtain the combinations which make up the permanent shocks: $:^{44}$

$u_{l, 1}=B^{\prime}{ }_{l, 1} e_{t}=0.422 e_{\text {lrev }, t}+0.228 e_{\text {lorev }, t}+e_{\text {lgov }, t}-0.303 e_{\text {leai }, t}+0.165 e_{\text {linf }, t}$

$u_{l, 2}=B_{l, 2}^{\prime} e_{t}=0.105 e_{\text {lrev }, t}+0.014 e_{\text {lorev }, t^{-}} 0.087 e_{\text {lgov }, t}+\boldsymbol{e}_{\text {leai, }, t}-0.139 e_{\text {linf }, t}$

$u_{l, 3}=B^{\prime}{ }_{l, 3} e_{t}=0.027 e_{\text {lrev }, t}+0.046 e_{\text {lorev }, t^{-}} 0.458 e_{\text {lgov }, t}+0.142 e_{\text {leai }, t}+\boldsymbol{e}_{\text {linf }, t}$

It can be observed that the first permanent shock is primarily given by shocks to government expenditure, the second one by shocks to economic activity and the third by shocks to inflation rate. Our results also suggest that the influence of oil revenue shocks may have fallen, an outcome which, given the finite nature of oil reserves, can be considered as positive. Finally, Table 9 and Figure 1 in Appendix II describe the dynamic impulse response functions after 17 periods for each of the system's variables resulting from a one standard deviation shock.

[Insert Table 9 and Figure 1 here]

We are able to verify that all transitory shocks have a zero long-run impact on the five variables, whereas all permanent shocks have a non-zero impact, except for oil revenues with respect to the second and third shocks and the identifying zero impact on government expenditure. Economic activity and inflation rate shocks have transitory impacts on oil revenues since this latter variable depends on both oil prices and oil national production, along with government demands. It can also be seen that tax revenues are affected permanently by the three permanent shocks: economic activity, government expenditure and inflation rate.

\footnotetext{
44 The first two rows give the combinations which make up the transitory shocks. Note that the second transitory shock is primarily given by shocks to government expenditure. Hence, government expenditure can be regarded as a source of transitory and permanent shock. It adjusts to long run relations as a transitory shock (See Table 7) but also it can be considered a pushing force that put the system out of equilibrium generating shocks with long run impact on the rest of the variables.
} 


\subsection{Robustness of results}

In order to gain robustness in our results, we impose other two hypotheses in our $\prod_{i}=\alpha \beta$ matrix to get identification, and consequently, another set of impulse responses functions ${ }^{45}$. First, we impose the structure of $H_{l}$ to identify the long run relations of the model. Table 7 shows these estimations; whilst Table 10 in the same Appendix defines how the orthogonalized permanent and transitory shocks are associated with the estimated CVAR residuals.

\section{[Insert Table 10 here]}

Table 11 and Figure 2 in Appendix II describe the dynamic impulse response functions, after 15 periods, for each of the system's variables resulting from a one standard deviation shock. Second, we test the hypothesis $H_{4}$. See Table 7 to check these latter estimations. Table 12 defines how the orthogonalized permanent and transitory shocks are associated with the estimated CVAR residuals.

\section{[Insert Tables 11 to 12 and Figure 2 here]}

Finally, Table 13 and Figure 3 describe the dynamic impulse response functions after 17 periods for each of the system's variables resulting from a one standard deviation shocks. As it can be seen, from these latter results, one can draw the same conclusions that were drawn with the first identification done on the long run structure.

[Insert Table 13 and Figure 3 here]

\footnotetext{
${ }^{45}$ Recall that the first set of impulse response corresponds to the structure of $\mathrm{H}_{3}$.
} 


\section{Concluding Remarks}

This article seeks to assess the impact of dollarization on Ecuador's fiscal sustainability given that this economy is strongly dependent on oil revenues which are particularly volatile because of price fluctuations, but have to finance increasing government expenditure in a context where, according to the OPEP, oil reserves will eventually vanish.

We have applied a CVAR approach inspired in the theoretical predictions of the intertemporal budget constraint theory. Our results suggest that fiscal policy in Ecuador seems to be sustainable, due to its low debt-to-GDP ratio, but there are three variables that tend to push the fiscal system out of equilibrium: economic activity, public spending and the inflation rate. Moreover, we have also found that (non-oil) tax revenues are purely adjusting variables, which means that their shocks do not have a permanent impact on the rest of the variables. Even though this result is consistent with Barro's (1979) tax smoothing theory, it may put the fiscal sustainability of a dollarized country at risk. Mainly, since oil revenues not only tend to adjust to public expenditures, but also to "displace" non-oil revenues.

In our opinion, this conclusion can be extended to other countries. First, many countries might face an important fiscal problem in the future due to aging population and the consequent increase in health care spending. Therefore, tax smoothing theory might not ensure fiscal sustainability (taxes should have a positive impact on output at long run, albeit they have a negative impact at short run). Second, not only a positive response of primary surplus to offset the rising debt service is needed to satisfy the intertemporal budget constrain, but taxes should have a positive long-term impact on activity. 
In the specific case of Ecuador, as a dollarized country, it might be difficult to achieve the needed primary surpluses since Ecuador not only cannot benefit from the "seignorage" revenues, but has also given up the exchange rate instrument which might be fundamental to encourage the development of sectors other than the oil one. Indeed, its reliance on volatile oil revenues, which eventually might vanish, leaves the economy's fiscal sustainability vulnerable to external and internal shocks.

Given the important policy implications of the analysis further extensions of the presented research are on our agenda. The inclusion of some other relevant variables in the model (such as a measure of the market exchange rate, the monetary and fiscal variables on the anchor country), or the extension of the sample period including the pre-dollarization period, might be useful to reassess the results.

\section{Acknowledgments}

This work was supported by the by the Government of Spain under Grant number ECO2013-4836. The authors would like to thank Katarina Juselius, Søren Johansen and Helena Chuliá for helpful comments. 


\section{References}

Alesina, A. and Barro, R.J. (2001). Dollarization. The American Economic Review, 92, 381-385.

Aggarwal, V. K. (1996). Debt Games: Strategic interaction in international debt rescheduling. Cambridge University Press.

Almeida, M ${ }^{a}$ D., Gallardo, V. and Tomaselli, A. (2006). Gobernabilidad fiscal en Ecuador. ECLAC Serie No 57. United Nations Press.

Alvarado, C., Izquierdo, A. and Panizza, U. (2004). Fiscal Sustainability in Emerging Market Countries with an Application to Ecuador. Inter-American Development Bank. Research Department. Working Paper No 511.

Barnhill, T., and Kopits, G. (2003). Assessing Fiscal Sustainability under Uncertainty. International Monetary Fund Working Paper 03/79. Washington, DC. United States.

Barro, R.M. (1979). On the Determination of Public Debt. Journal of Political Economy, 87, 940-947.

Barro, R.M. (1986). U.S. Deficits since World War I. Scandinavian Journal of Economics, 88, 195-222.

Berg. A and Borensztein, E. (2000). The Pros and Cons of full dollarization, International Monetary Fund Working Paper Working Paper 00/50. Washington, DC. United States.

Bohn, H. (1998). The Behaviour of U.S. public debt and deficits. Quarterly Journal of Economics, 113, 949-963.

Bohn, H. (2005). The sustainability of fiscal policy in the United States. CESifo Working Papers No. 1446. Munich, Germany.

Bohn, H. (2007). Are stationarity and cointegration restrictions really necessary for the intertemporal budget constraint? Journal of Monetary Economics, 54, 1837-1847.

Calvo, G. A. and Reinhart, C.M. (2002). Fear of Floating, Quarterly Journal of Economics, 117, 379-408.

ECLAC (2006). Preliminary Overview of the Economies of Latin America and the Caribbean. 
Chang, R. (2000). Dollarization: A Scorecard. Economic Review, Federal Reserve Bank of Atlanta, 92, 1-11.

Collignon, S. (2012). Fiscal Policy Rules and the sustainability of public debt in Europe. International Economic Review, 53, 539-567.

Cueva, S. (2008).Ecuador: Fiscal Stabilization Funds and Prospects. Inter-American Development Bank. Country Department Andean Group (CAN). Working Paper CSI110. EC-P1059.

Cheung, Y. W. and Lai, K. S. (1993). Finite sample of Johansen's likelihood ratio tests for cointegration. Oxford Bulletin of Economics and Statistics, 55, 313-328.

De Nicoló, G., Honohan, P. and Ize, A. (2005). Dollarization of bank deposits: Causes and consequences. Journal of Banking and Finance, 29, 1697-1727.

Doane, D.P. and Seward, L.E. (2011). Measuring Skewness: A Forgotten Statistic?. Journal of Statistics Education, 19, 1-18.

Duttagupta R. and Tolosa G. (2006). Fiscal discipline and exchange rate regimen: evidence from the Caribbean. International Monetary Fund Working Paper No. 06/119. Washington, DC. United States.

Ecuador Central Bank. (2013). Estadísticas Macroeconómicas: Presentación estructural. Edwards, S. (1988). The debt crisis and economic adjustment in Latin America. University of California, Los Angeles, Working Paper No 531.

Edwards, S. (2008). Globalization, growth and crises: the view from Latin America. National Bureau of Economic Research Working Paper No 14034. Cambridge, MA. United States.

El Anshasy, A. A. and Bradley, M. D. (2012). Oil prices and the fiscal policy response in oil-exporting countries. Journal of Policy Modeling, 34, 605-620.

Engle, R. F. and Granger, C.W.J. (1987). Cointegration and error correction: Representation, estimation, and testing. Econometrica, 55, 251-276.

Estadísticas Macroeconómicas. Presentación estructural (2013). Ecuador Central Bank.

Favero, C., Giavazzi, F. and Perego, J. (2011). Country Heterogeneity and the International Evidence on the Effects of Fiscal Policy. International Monetary Fund Economic Review, 59, 652-682. 
Favero, C., Giavazzi, F. (2007). Debt and the Effects of Fiscal Policy. National Bureau of Economic Research Working Papers No 12822. Cambride, MA. United States.

Federal Deposit Insurance Corporation, Division of Research and Statistics. (1997). History of the eighties: lessons for the future. Washington, DC. United States.

Fincke, B. and Greiner, A. (2012). How to assess debt sustainability? Some theory and empirical evidence for selected euro area countries. Applied Economics, 44, 3717-3724. Goldfajn, I. and Olivares G. (2000). Is Adopting Full Dollarization the Solution? A Look at the Evidence. Working Paper No 146. Pontifícia Universidade Católica do Rio de Janeiro.

Grandes, M. and Reisen, H. (2003). Hard Peg versus Soft Float: A Tale of Two LatinAmerican Countries. Revue Economique, 54, 1059-1090.

Hamilton J. and Flavin, M. (1986). On the Limitations of Government Borrowing: A Framework for Empirical Testing. American Economic Review, 76, 808-819.

Hendry, D.F. (1995). Dynamic Econometrics. Oxford University Press, Oxford.

Hoover, K., Johansen, S. and Juselius, K. (2007). Allowing the data to speak freely: The macroeconometrics of the cointegrated vector autoregression. American Economic Review, 98, 251-55.

Jacome, L. (2004). The late 1990s financial crisis in Ecuador: institutional weaknesses, fiscal rigidities, and financial dollarization at work, International Monetary Fund Working Papers No. 04/12. Washington DC. United States.

Johansen, S. (1996). Likelihood-Based Inference in Cointegrated Vector Autoregressive Models, 2.edn. Advanced Texts in Econometrics, Oxford University Press: Oxford.

Johansen, S. and Juselius, K. (1990). Maximum likelihood estimation and inference on cointegration with application to the demand of money. Oxford Bulletin of Economics and Statistics, 52, 169-210.

Johansen, S. and Juselius, K. (1992). Testing structural hypotheses in a multivariate cointegration analysis of the PPP and the UIP for UK. Journal of Econometrics, 53, 211-244.

Juselius, K. (2006). The Cointegrated VAR Model: Methodology and Applications, 1st edn, Oxford University Press, USA. 
Kia, A. (2008). Fiscal sustainability in emerging countries: Evidence from Iran and Turkey. Journal of Policy Modeling, 30, 957-972.

Konstantinou, P.T. (2004). Balancing the budget through revenue or spending adjustments? The case of Greece. Journal of Development, 81, 81-105.

Levy-Yeyati, E. and Sturzenegger, F. (2003). To Float or to Fix. American Economic Review, 93, 173-1193.

Lütkepohl, H. (2004). Univariate time series analysis in Applied Time Series Econometrics, 1st edn (Eds) H. Lütkepohl and M. Krätzig, Cambridge University Press, Cambridge, pp. 8-85.

Marí Del Cristo, M.L. and Gómez-Puig, M. (2013). Pass-through in dollarized countries: should Ecuador abandon the US dollar? Applied Economics, 45, 4359-4375.

Martins, P.M.G. (2010). Fiscal dynamics in Ethiopia: the cointegrated VAR model with quarterly data. Centre for Research in Economic Development and International Trade, CREDIT Research Paper No 10/05.

Mejía, A., Albornoz, V. and Araujo, M. (2006) .The Political Economy of the Budget Process: The Case of Ecuador. Inter-American Development Bank. Regional Operations Department 3 (RE3). Country Studies Series Working Paper CS-101.

Perotti, R. (2002). Estimating the effects of fiscal policy in OECD countries. European Central Bank Working Papers Series No 168. Frankfurt, Germany.

Quispe-Agnoli, M. and Whisler, E. (2006). Official Dollarization and the Banking System in Ecuador and El Salvador. Federal Reserve Bank of Atlanta. Economic Review. Third Quarter.

Rahbek A, Hansen E, Dennis J. G. (2002). ARCH Innovations and their impact on cointegration rank testing. Working Paper No.22, Centre for Analytical Finance. University of Copenhagen.

Ramsey, F.P. (1928). A Mathematical Theory of Saving. Economic Journal, 38, 543559.

Ray, R. and Kozameh, S. (2012). Ecuador's Economy Since 2007. Center for Economic and policy research. Available at http://www.cepr.net/ 
Reinhart, C. M. and Rogoff K. S. (2004). The Modern History of Exchange Rate Arrangements: A Reinterpretation. The Quarterly Journal of Economics, 119, 1-48.

Romer Ch. and Romer, D. (2010).The Macroeconomic Effects of Tax Changes: Estimates Based on a New Measure of Fiscal Shocks. American Economic Review, 100, 763-801.

Sandoval, L. and Weisbrot, M. (2009). Update on the Ecuadorian Economy. Center for Economic and policy research. Available at http://www.cepr.net/

The World Bank and Inter-American development Bank. (2004). Ecuador, Creating Fiscal Space for Poverty Reduction. A Fiscal Management and Public Expenditure Review, Report No. 28911-EC.

Tornell, A. and Velasco, A. (1998). Fiscal discipline and the choice of a nominal anchor in stabilization. Journal of International Economics, 46, 1-30

Tornell, A. and Velasco, A. (2000). Fixed versus flexible exchange rates: Which provides more fiscal discipline? Journal of Monetary Economics, 45, 399-436.

Trehan, B. and Walsh, C. (1991). Testing Intertemporal Budget Constraints: Theory and Applications to U.S. Federal Budget and Current Account Deficits. Journal of Money, Credit and Banking, 23, 210-223.

Vladimirov, V., and Neycheva, M. (2009). Determinants of Non-linear Effects of Fiscal Policy on Output: The Case of Bulgaria. South East European Journal of Economics and Business, 4, 51-61. 


\section{Appendix I}

Figure A: Total Debt-to-GDP ratio

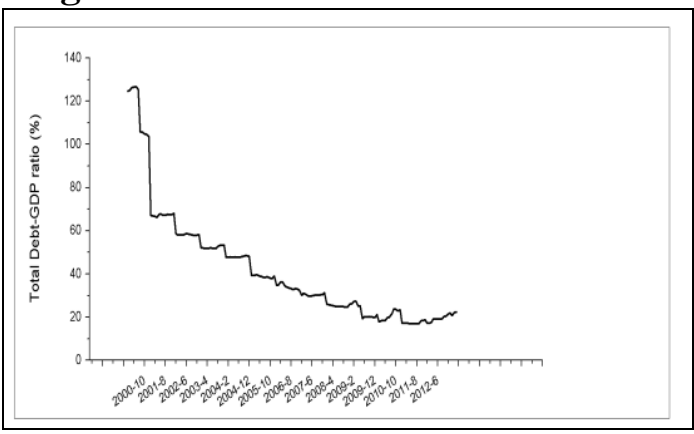

Figure B: Primary balance variables

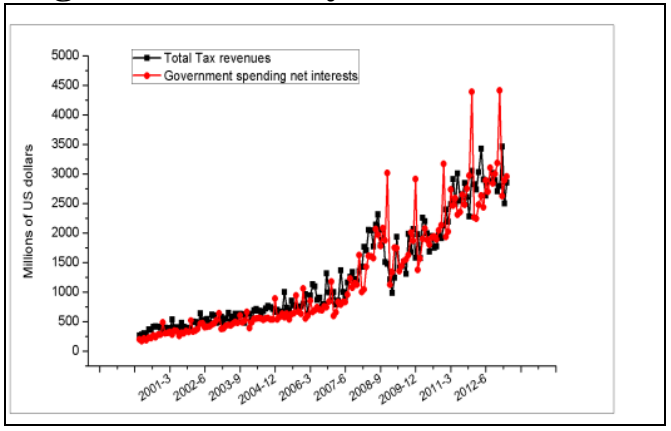

Source: Central Bank of Ecuador and our own estimates.

Figure C: Ecuadorian Inflation rate

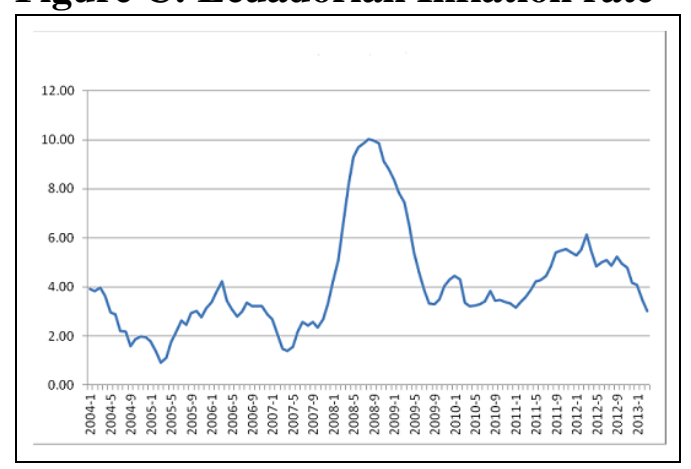

Source: Central Bank of Ecuador
Figure D: EAI and Active interest rate

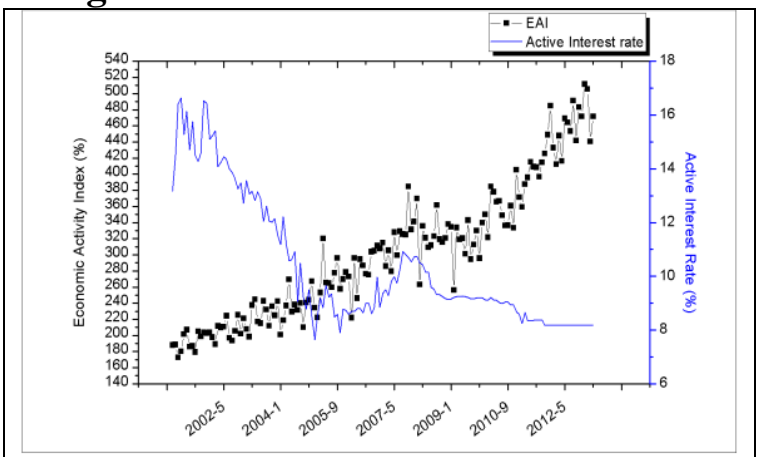

Table A: Description of variables

\begin{tabular}{|c|c|c|c|}
\hline Variable & Description & Unit & Source \\
\hline $\begin{array}{l}\text { Total Government } \\
\text { spending }\left(L T G O V_{t}\right)\end{array}$ & $\begin{array}{l}\text { Government purchases of goods and } \\
\text { services (current consumption, gross } \\
\text { fixed capital formation, wages) + } \\
\text { interests. }\end{array}$ & $\begin{array}{l}\text { Millions of } \\
\text { U.S. dollars }\end{array}$ & $\begin{array}{l}\text { Monthly Information } \\
\text { Bulletin. Central Bank of } \\
\text { Ecuador (CBE) }\end{array}$ \\
\hline $\begin{array}{l}\text { Government spending net } \\
\text { interest }\left(L G O V_{t}\right)\end{array}$ & Total Government spending - interests & $\begin{array}{l}\text { Millions of } \\
\text { U.S. dollars }\end{array}$ & $\begin{array}{l}\text { Monthly Information } \\
\text { Bulletin CBE }\end{array}$ \\
\hline Interests $\left(L I N_{\mathrm{t}}\right)$ & Both external and internal debt interests & $\begin{array}{l}\text { Millions of } \\
\text { U.S. dollars }\end{array}$ & $\begin{array}{l}\text { Monthly Information } \\
\text { Bulletin CBE }\end{array}$ \\
\hline $\begin{array}{l}\text { Economic Activity Index } \\
\text { (IDEAC, the acronym in } \\
\left.\text { Spanish }\left(L E A I_{t}\right)\right)\end{array}$ & $\begin{array}{l}\text { Describing the variation in volume of } \\
\text { Ecuadorian economic activity }\end{array}$ & Index & $\begin{array}{l}\text { Monthly Information } \\
\text { Bulletin CBE }\end{array}$ \\
\hline Total Revenues $\left(L T R E V_{t}\right)$ & $\begin{array}{l}\text { Tax revenues + oil revenues }+ \text { public } \\
\text { enterprises surplus }\end{array}$ & $\begin{array}{l}\text { Millions of } \\
\text { U.S. dollars }\end{array}$ & $\begin{array}{l}\text { Monthly Information } \\
\text { Bulletin CBE }\end{array}$ \\
\hline Oil revenues $\left(L O R E V_{t}\right)$ & $\begin{array}{l}\text { Oil revenues from exports and sale of its } \\
\text { derivatives }\end{array}$ & $\begin{array}{l}\text { Millions of } \\
\text { U.S. dollars }\end{array}$ & $\begin{array}{l}\text { Monthly Information } \\
\text { Bulletin CBE }\end{array}$ \\
\hline Tax Revenues $\left(L R E V_{t}\right)$ & Revenues from direct and indirect taxes & $\begin{array}{l}\text { Millions of } \\
\text { U.S. dollars }\end{array}$ & $\begin{array}{l}\text { Monthly Information } \\
\text { Bulletin CBE }\end{array}$ \\
\hline Inflation $\left(L I N F_{t}\right)$ & Annual inflation. & Percentage & $\begin{array}{l}\text { Monthly Information } \\
\text { Bulletin CPI (ECB) }\end{array}$ \\
\hline Active interest rate $\left(A I R_{t}\right)$ & $\begin{array}{l}\text { Short term interest rate. Credit cost to } \\
\text { three months. }\end{array}$ & Percentage & ECLAC \\
\hline
\end{tabular}




\section{Appendix II}

Table 1. Trace test for the first model:

$X_{t}=\left[L R E V_{t}, L O R E V_{t}, L G O V_{t}, L E A I_{t}, L I N F_{t}, L D E B T_{-} G D P_{t}\right]$

\begin{tabular}{|c|c|c|l|c|c|c|c|}
\hline $\mathbf{r}$ & $\mathbf{p}-\mathbf{r}$ & Eig.Value & Trace & Trace* & Frac95 & p-value & p-value* \\
\hline 0 & 6 & 0.457 & 192.799 & 183.030 & 95.514 & 0.000 & 0.000 \\
\hline 1 & 5 & 0.300 & 99.941 & 95.351 & 69.611 & 0.000 & 0.000 \\
\hline 2 & 4 & 0.137 & 45.755 & 43.652 & 47.707 & 0.076 & 0.117 \\
\hline 3 & 3 & 0.077 & 23.315 & 22.173 & 29.804 & 0.239 & 0.298 \\
\hline 4 & 2 & 0.048 & 11.100 & 10.035 & 15.408 & 0.209 & 0.283 \\
\hline 5 & 1 & 0.024 & 3.640 & 3.102 & 3.841 & 0.056 & 0.078 \\
\hline
\end{tabular}

Notes: Trace test without seasonal or dummies variables. *Bartell correction for small samples.

Table 2. Tests of stationarity and long-run exclusion for the first model: $X_{t}=\left[L R E V_{t}, L O R E V_{t}, L G O V_{t}, L E A I_{t}, L I N F_{t}, L D E B T_{-} G D P_{t}\right]$

\begin{tabular}{|l|c|c|c|c|c|c|c|}
\hline Test & 5\% C.V. $^{\text {LREV }} \boldsymbol{t}$ & LOREV $_{\boldsymbol{t}}$ & LGOV $_{\boldsymbol{t}}$ & LEAI $_{\boldsymbol{t}}$ & LINF $_{\boldsymbol{t}}$ & LDEBT_GDP $_{\boldsymbol{t}}$ \\
\hline Stationarity & 9.488 & 30.327 & 28.936 & 30.161 & 30.687 & 30.371 & 27.877 \\
\hline p-value & --- & 0.000 & 0.000 & 0.000 & 0.000 & 0.000 & 0.000 \\
\hline Exclusion & 5.991 & 51.091 & 21.727 & 38.972 & 13.319 & 6.639 & 0.260 \\
\hline p-value & --- & 0.000 & 0.000 & 0.000 & 0.001 & 0.036 & 0.878 \\
\hline
\end{tabular}

Notes: P-values of 0.05 based on $\chi^{2}(r)$.

Table 3. Trace test for the second model:

$X_{t}=\left[L R E V_{t}, L O R E V_{t}, L G O V_{t}, L E A I_{t}, L I N F_{t}\right]$

\begin{tabular}{|c|c|c|c|c|c|c|c|}
\hline $\mathbf{r}$ & $\mathbf{p}-\mathbf{r}$ & Eig. Value & Trace & Trace* $^{*}$ & Frac95 & p-value & p-value* \\
\hline 0 & 5 & 0.446 & 168.47 & 161.39 & 69.611 & 0.000 & 0.000 \\
\hline 1 & 4 & 0.283 & 78.655 & 75.700 & 47.707 & 0.000 & 0.000 \\
\hline 2 & 3 & 0.105 & 28.033 & 26.967 & 29.804 & 0.08 & 0.105 \\
\hline 3 & 2 & 0.062 & 11.095 & 10.508 & 15.408 & 0.209 & 0.248 \\
\hline 4 & 1 & 0.009 & 1.422 & 1.243 & 3.841 & 0.233 & 0.265 \\
\hline
\end{tabular}

Notes: Trace test without seasonal or dummies variables. *Bartell correction for small samples.

Table 4. Tests of long-run exclusion for the second model:

$X_{t}=\left[L R E V_{t}, L O R E V_{t}, L G O V_{t}, L_{E A I}, L_{I N F_{t}}\right]$

\begin{tabular}{|l|c|c|c|c|c|c|}
\hline Test & 5\% C.V. & LREV $_{\boldsymbol{t}}$ & LOREV $_{\boldsymbol{t}}$ & LGOV $_{\boldsymbol{t}}$ & LEAI $_{\boldsymbol{t}}$ & $\boldsymbol{L I N F}_{\boldsymbol{t}}$ \\
\hline Exclusion & 5.991 & 54.630 & 22.244 & 41.939 & 15.203 & 5.967 \\
\hline p-value & --- & 0.000 & 0.005 & 0.000 & 0.000 & 0.051 \\
\hline
\end{tabular}

Notes: P-values of 0.05 based on $\chi^{2}(\mathrm{r})$. 
Table 5. Tests of hypothesis on $\beta$ for the second model: $X_{t}=\left[L R E V_{t}, L O R E V_{t}, L G O V_{t}, L E A I_{t}, L I N F_{t}\right]$

\begin{tabular}{|l|l|c|c|c|}
\hline Hypothesis* & $\begin{array}{l}\text { Test of stationarity of linear } \\
\text { combinations }\end{array}$ & Degrees of Freedom & Statistic & p-value \\
\hline $\boldsymbol{H}_{\boldsymbol{I}}$ : Balanced budget & $L G O V_{t}-c^{*} L R E V_{t}-(1-c)^{*} L O R E V_{t}$ & $\chi^{2}(1)$ & 1.301 & 0.254 \\
\hline $\begin{array}{l}\boldsymbol{H}_{2}: \text { Balanced budget } \\
\text { without oil revenues }\end{array}$ & $L G O V_{t}-c^{*} L R E V_{t}$ & $\chi^{2}(2)$ & 23.707 & 0.000 \\
\hline $\boldsymbol{H}_{3}:$ Additionality & $L G O V_{t}-L O R E V_{t}$ & $\chi^{2}(3)$ & 3.023 & 0.388 \\
\hline $\boldsymbol{H}_{4}:$ Tax displacement & $L R E V_{t}-c^{*} L O R E V_{t}$ & $\chi^{2}(2)$ & 5.799 & 0.055 \\
\hline
\end{tabular}

Notes: *Hypothesis on one specific vector without imposing restrictions on the other.

Table 6. Tests of hypothesis on $\alpha$ for the second model $X_{t}=\left[L R E V_{t}, L O R E V_{t}, L G O V_{t}, L E A I_{t}, L I N F_{t}\right]$

\begin{tabular}{|l|c|c|c|c|c|c|}
\hline Test & $\mathbf{5 \%}^{\text {C.V }}$ & LREV $_{\boldsymbol{t}}$ & LOREV $_{\boldsymbol{t}}$ & LGOV $_{\boldsymbol{t}}$ & LEAI $_{\boldsymbol{t}}$ & IINF $_{\boldsymbol{t}}$ \\
\hline Exogeneity & 5.991 & 40.680 & 18.726 & 12.310 & 3.016 & 3.853 \\
\hline p-value & --- & 0.000 & 0.000 & 0.002 & 0.221 & 0.146 \\
\hline Unit Vector & 7.815 & 7.337 & 9.067 & 23.875 & 24.170 & 26.226 \\
\hline p-value & --- & 0.062 & 0.028 & 0.000 & 0.000 & 0.000 \\
\hline
\end{tabular}

Notes: P-values of 0.05 based on $\chi^{2}(r)$.

Table 7. Identifying restriction imposed on the 2nd beta vector and specific hypothesis imposed on the first one. $X_{t}=\left[L R E V_{t}, L O R E V_{t}, L G O V_{t}, L E A I_{t}, L I N F_{t}\right]$

\begin{tabular}{|c|c|c|c|c|c|c|}
\hline & $\hat{\beta}_{1}, H_{1}$ & $\hat{\beta}_{2}, H_{1}$ & $\hat{\beta}_{1}, H_{3}$ & $\hat{\beta}_{1}, H_{3}$ & $\hat{\beta}_{1}, H_{4}$ & $\hat{\beta}_{1}, H_{4}$ \\
\hline$L R E V_{t}$ & 1 & 0 & 0 & 1 & 1 & 0 \\
\hline LOREV $V_{t}$ & $\begin{array}{c}1.262 \\
{[44.644]} \\
\end{array}$ & 1 & -1 & 0 & $\begin{array}{c}-0.743 \\
{[-31.082]}\end{array}$ & 1 \\
\hline$L G O V_{t}$ & $\begin{array}{c}-2.106 \\
{[-28.276]}\end{array}$ & $\begin{array}{c}-1.209 \\
{[-20.065]}\end{array}$ & 1 & $\begin{array}{c}-0.58 \\
{[-16.541]}\end{array}$ & 0 & $\begin{array}{c}-0.796 \\
{[-14.961]}\end{array}$ \\
\hline$L_{E A I_{t}}$ & 0 & $\begin{array}{c}0.411 \\
{[5.218]} \\
\end{array}$ & 0 & $\begin{array}{c}-0.523 \\
{[-5.308]}\end{array}$ & 0 & $\begin{array}{c}-0.666 \\
{[-5.231]}\end{array}$ \\
\hline \multirow[t]{2}{*}{$L^{\prime N N F_{t}}$} & 0 & $\begin{array}{c}-0.022 \\
{[-2.639]}\end{array}$ & 0 & $\begin{array}{c}0.026 \\
{[2.497]}\end{array}$ & 0 & $\begin{array}{c}0.028 \\
{[2.050]}\end{array}$ \\
\hline & $\hat{\alpha}_{1}, H_{1}$ & $\hat{\alpha}_{2}, H_{1}$ & $\hat{\alpha_{1}, H_{3}}$ & $\hat{\alpha}_{2}, H_{3}$ & $\hat{\alpha_{1}, H_{4}}$ & $\hat{\alpha}_{2}, H_{4}$ \\
\hline$\overline{L R E V_{t}}$ & $\begin{array}{c}-0.843 \\
{[-6.826]}\end{array}$ & $\begin{array}{c}1.106 \\
{[6.996]}\end{array}$ & $\begin{array}{c}-0.038 \\
{[-1.187]}\end{array}$ & $\begin{array}{c}-0.836 \\
{[-6.771]} \\
\end{array}$ & $\begin{array}{c}-0.815 \\
{[-6.614]}\end{array}$ & $\begin{array}{c}-0.576 \\
{[-5.807]}\end{array}$ \\
\hline$L O R E V_{t}$ & $\begin{array}{c}0.237 \\
{[0.754]}\end{array}$ & $\begin{array}{c}-0.712 \\
{[-1.774]}\end{array}$ & $\begin{array}{c}0.415 \\
{[5.177]}\end{array}$ & $\begin{array}{c}0.219 \\
{[0.703]}\end{array}$ & $\begin{array}{c}0.179 \\
{[0.578]}\end{array}$ & $\begin{array}{c}-0.275 \\
{[-1.101]}\end{array}$ \\
\hline$L_{L G O V_{t}}$ & $\begin{array}{c}0.316 \\
{[2.648]}\end{array}$ & $\begin{array}{c}-0.310 \\
{[-2.034]} \\
\end{array}$ & $\begin{array}{c}-0.075 \\
{[-2.446]}\end{array}$ & $\begin{array}{c}0.320 \\
{[2.669]}\end{array}$ & $\begin{array}{c}0.335 \\
{[2.815]} \\
\end{array}$ & $\begin{array}{c}0.314 \\
{[3.275]} \\
\end{array}$ \\
\hline$L E A I_{t}$ & $\begin{array}{c}0.129 \\
{[1.627]}\end{array}$ & $\begin{array}{c}-0.154 \\
{[-1.524]}\end{array}$ & $\begin{array}{c}-0.015 \\
{[-0.762]}\end{array}$ & $\begin{array}{c}0.132 \\
{[1.680]}\end{array}$ & $\begin{array}{c}0.132 \\
{[1.693]}\end{array}$ & $\begin{array}{c}0.122 \\
{[1.944]}\end{array}$ \\
\hline$L I N F_{t}$ & $\begin{array}{c}0.131 \\
{[0.918]} \\
\end{array}$ & $\begin{array}{c}-0.110 \\
{[-0.601]}\end{array}$ & $\begin{array}{c}-0.050 \\
{[-1.374]}\end{array}$ & $\begin{array}{c}0.140 \\
{[0.983]} \\
\end{array}$ & $\begin{array}{c}0.167 \\
{[1.180]} \\
\end{array}$ & $\begin{array}{c}0.156 \\
{[1.366]} \\
\end{array}$ \\
\hline
\end{tabular}

Notes: $\log$-Likelihood $\left(\mathrm{H}_{1}\right)=1673.47, \log$-Likelihood $\left(\mathrm{H}_{3}\right)=1672.61, \log$-Likelihood $\left(\mathrm{H}_{4}\right)=1671.22$; $\mathrm{t}$-values in brackets. 
Table 8. Normalized $B$ matrix (with $\mathrm{H}_{3}$ )

\begin{tabular}{|l|c|c|c|c|c|}
\hline & $\boldsymbol{e}_{\text {LREVt }}$ & $\boldsymbol{e}_{\text {LOREVt }}$ & $\boldsymbol{e}_{\text {LGOVt }}$ & $\boldsymbol{e}_{\text {LEAIt }}$ & $\boldsymbol{e}_{\text {LINFt }}$ \\
\hline Trans(1) & 1.000 & -0.125 & -0.454 & -0.517 & 0.022 \\
\hline Trans(2) & -0.421 & -0.568 & 1.000 & 0.459 & 0.394 \\
\hline Perm(1) & 0.422 & 0.228 & 1.000 & -0.303 & 0.165 \\
\hline Perm(2) & 0.105 & 0.014 & -0.087 & 1.000 & -0.139 \\
\hline Perm(3) & 0.027 & 0.046 & -0.458 & 0.142 & 1.000 \\
\hline
\end{tabular}

Notes: The estimated B matrix is normalized at the largest coefficient at the each row defines how the orthogonalized permanent (Perm) and transitory (Trans) shocks are associated with the estimated VAR residuals through the equation ut $=$ Bet.

Table 9. Impact after 17 periods (with $\mathrm{H}_{3}$ )

\begin{tabular}{|l|c|c|c|c|c|}
\hline & Trans(1) & Trans(2) & Perm(1) & Perm(2) & Perm(3) \\
\hline LRE $_{\boldsymbol{t}}$ & 0.001 & -0.003 & 4.195 & 2.207 & 0.544 \\
\hline LOREV $_{\boldsymbol{t}}$ & -0.007 & 0.024 & 7.186 & -0.003 & -0.025 \\
\hline LGOV $_{\boldsymbol{t}}$ & 0.001 & -0.005 & 7.171 & 0.001 & 0.005 \\
\hline LEAI $_{t}$ & -0.000 & 0.000 & 0.369 & 4.107 & -0.000 \\
\hline LINF $_{\boldsymbol{t}}$ & 0.003 & -0.012 & 6.003 & -2.201 & -20.905 \\
\hline
\end{tabular}

Notes: The estimates of $\mathrm{C} \sim$ are the long run value of the 17 impulse response functions. The first two columns describe the zero long run affect of the transitory shocks on the variables of the system, and the last three columns describe the long run effect of the permanent shocks, i.e. the structural second permanent shock ul2,t is defined as $u_{l 2, t}=C_{L E A I_{t}}^{\sim} e_{t}$ where $C_{L E A I_{t}}^{\sim}$ is the LEIAt row in the C $\sim$ matrix.

Figure 1: IRF for the permanent and transitory shocks with $H_{3}$ (17-period effects)

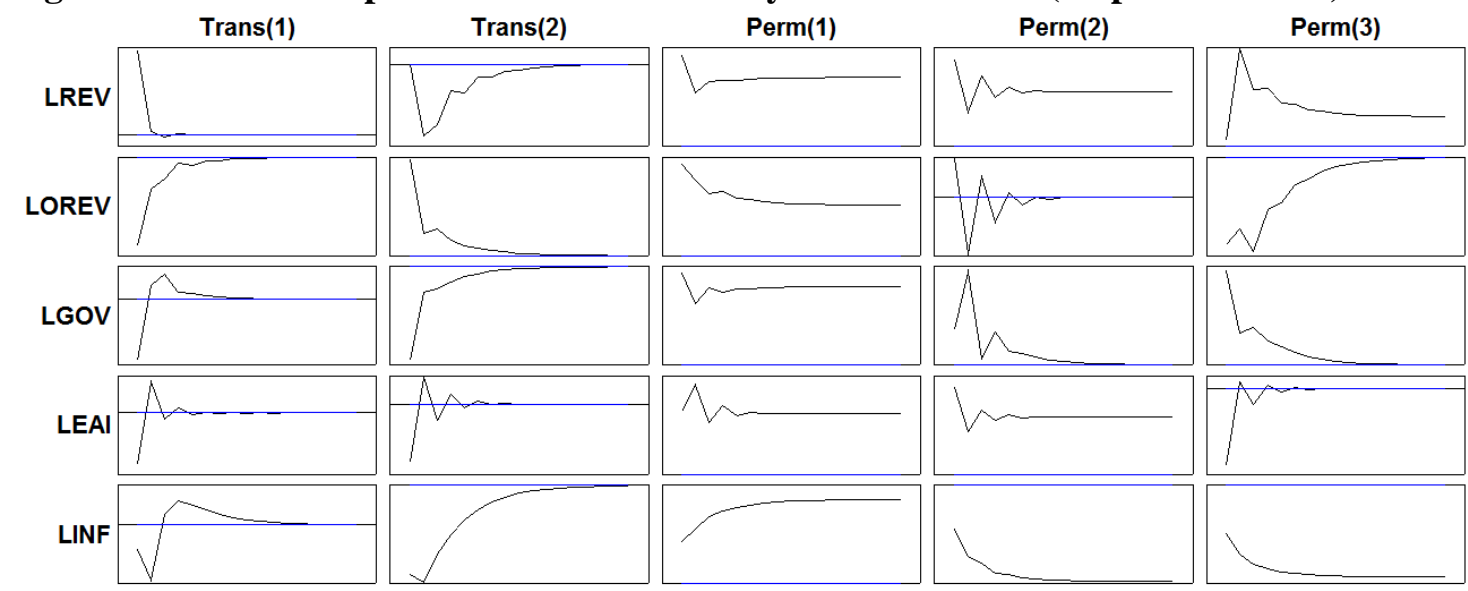

Notes: Fig. 1 illustrates the dynamic impulse response functions for each of the system variables as a result of a one standard deviation shock to the $\mathrm{u}_{i, t}, i=1, \ldots \mathrm{p}$. 
Table 10. Normalized $B$ matrix (with $\mathrm{H}_{1}$ ).

\begin{tabular}{|l|l|l|l|l|l|}
\hline & $\boldsymbol{e}_{\text {LREVt }}$ & $\boldsymbol{e}_{\text {LOREVt }}$ & $\boldsymbol{e}_{\text {LGOVt }}$ & $\boldsymbol{e}_{\text {LEAIt }}$ & $\boldsymbol{e}_{\text {LINFt }}$ \\
\hline Trans(1) & 1.000 & -0.124 & -0.424 & -0.551 & 0.037 \\
\hline Trans(2) & -0.376 & -0.488 & 1.000 & 0.212 & 0.378 \\
\hline Perm(1) & 0.442 & 0.275 & 1.000 & -0.223 & 0.155 \\
\hline Perm(2) & 0.098 & -0.007 & -0.080 & 1.000 & -0.143 \\
\hline Perm(3) & 0.021 & 0.041 & -0.469 & 0.193 & 1.000 \\
\hline
\end{tabular}

Notes: The estimated B matrix is normalized at the largest coefficient at the each row defines how the orthogonalized permanent (Perm) and transitory (Trans) shocks are associated with the estimated VAR residuals through the equation $u t=$ Bet.

Table 11. Impact after 15 periods (with $\left.\mathrm{H}_{1}\right)$.

\begin{tabular}{|l|c|c|c|c|c|}
\hline & Trans(1) & Trans(2) & Perm(1) & Perm(2) & Perm(3) \\
\hline LRE $_{\boldsymbol{t}}$ & 0.001 & -0.005 & 4.163 & 2.197 & 0.587 \\
\hline LORE $_{\boldsymbol{t}}$ & -0.009 & 0.032 & 8.518 & -1.800 & -0.508 \\
\hline LGOV $_{\boldsymbol{t}}$ & 0.002 & -0.009 & 7.049 & 0.001 & 0.008 \\
\hline LEAI $_{t}$ & -0.000 & 0.001 & 0.463 & 4.110 & -0.001 \\
\hline LINF $_{\boldsymbol{t}}$ & 0.006 & -0.020 & 5.939 & -2.496 & -20.812 \\
\hline
\end{tabular}

Notes: The estimates of $\mathrm{C} \sim$ are the long run value of the 15 impulse response functions. The first two columns describe the zero long run affect of the transitory shocks on the variables of the system, and the last three columns describe the long run effect of the permanent shocks, i.e. the structural second permanent shock ul2,t is defined as $u_{l 2, t}=C_{L E A I_{t}}^{\sim} e_{t}{ }_{\text {where }}^{\sim} C_{L E A I_{t}}$ is the LEIAt row in the C $\sim$ matrix.

Figure 2: IRF for the permanent and transitory shocks with $H_{I}$ (15-period effects).

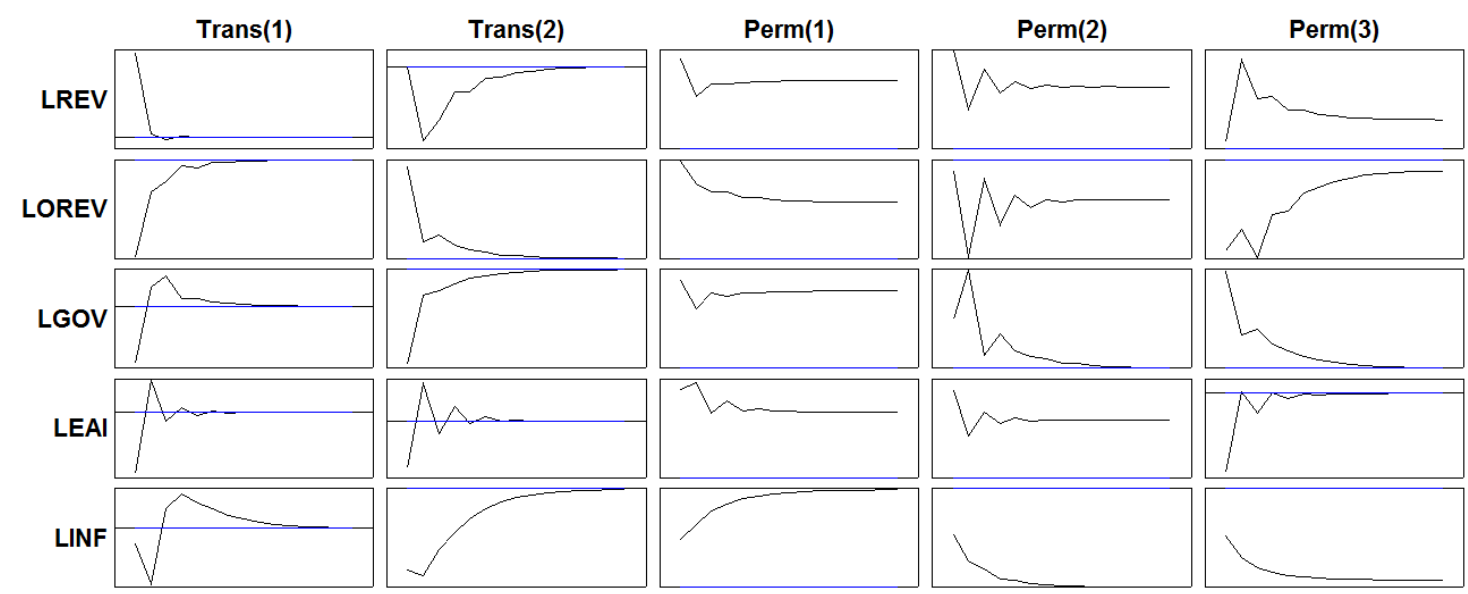

Notes: Fig. 2 illustrates the dynamic impulse response functions for each of the system variables as a result of a one standard deviation shock to the $\mathrm{u}_{i, t}, i=1, \ldots \mathrm{p}$. 
Table 12. Normalized $B$ matrix (with $\mathrm{H}_{4}$ ).

\begin{tabular}{|l|c|c|c|c|c|}
\hline & $\boldsymbol{e}_{\text {LREVt }}$ & $\boldsymbol{e}_{\text {LOREVt }}$ & $\boldsymbol{e}_{\text {LGOVt }}$ & $\boldsymbol{e}_{\text {LEAIt }}$ & $\boldsymbol{e}_{\text {LINFt }}$ \\
\hline Trans(1) & 1.000 & -0.129 & -0.489 & -0.447 & -0.033 \\
\hline Trans(2) & -0.477 & -0.634 & 1.000 & 0.802 & 0.281 \\
\hline Perm(1) & 0.423 & 0.180 & 1.000 & -0.385 & 0.166 \\
\hline Perm(2) & 0.107 & 0.042 & -0.092 & 1.000 & -0.130 \\
\hline Perm(3) & 0.053 & 0.021 & -0.411 & 0.076 & 1.000 \\
\hline
\end{tabular}

Notes: The estimated B matrix is normalized at the largest coefficient at the each row defines how the orthogonalized permanent (Perm) and transitory (Trans) shocks are associated with the estimated VAR residuals through the equation ut $=$ Bet

Table 13. Impact after 17 periods (with $\left.\mathrm{H}_{4}\right)$.

\begin{tabular}{|c|c|c|c|c|c|}
\hline & Trans(1) & Trans(2) & Perm(1) & $\operatorname{Perm}(2)$ & $\overline{\operatorname{Perm}(3)}$ \\
\hline$L R E V_{t}$ & 0.001 & -0.003 & 4.294 & 2.039 & 0.424 \\
\hline$L O R E V_{t}$ & -0.007 & 0.024 & 5.793 & 2.740 & 0.545 \\
\hline$L G O V_{t}$ & 0.001 & -0.004 & 7.207 & 0.001 & 0.004 \\
\hline LEAI & 0.000 & -0.001 & 0.290 & 4.053 & 0.001 \\
\hline$L I N F_{t}$ & 0.002 & -0.006 & 5.440 & -1.625 & -20.496 \\
\hline
\end{tabular}

Notes: The table 13 describes the estimates of $\mathrm{C} \sim$ which are the long run value of the 17 impulse response functions. The first two columns describe the zero long run affect of the transitory shocks on the variables of the system, and the last three columns describe the long run effect of the permanent shocks, i.e. the structural second permanent shock ul2,t is defined as $u_{l 2, t}=C_{L_{E A I}{ }_{t}}^{\sim}$ where $C_{L E A I_{t}}^{\sim}$ is the LEIAt row in $C^{\sim}$ the matrix.

Figure 3: IRF for the permanent and transitory shocks with $H_{4}(17$-period effects).



Notes: Fig. 3 illustrates the dynamic impulse response functions for each of the system variables as a result of a one standard deviation shock to the $\mathrm{u}_{i, t}, i=1, \ldots \mathrm{p}$. 